\title{
Family literacy: a project to get parents involved
}

\author{
Myrna Machet \\ Department of Information Science, Unisa, PO Box 392, Pretoria 0003 \\ machemp@unisa.ac.za
}

and

Elizabeth J Pretorius

Department of Linguistics, Unisa, PO Box 392, Pretoria 0003

\begin{abstract}
Received: 18th October 2002
Revised: 3 June 2003

In this article family literacy as a strategy to address the problem of a lack of preliteracy skills in preschool children will be discussed. A family literacy project developed by the Children's Literature Research Unit in the Department of Information Science, at Unisa in partnership with Project Literacy will be described. This project was started in 2000 in four creches and has now expanded to 19 sites in KwaZulu Natal, Eastern Cape, Limpopo Province and Gauteng. The methodology used and the results from one of the sites will be given. Finally, the role of community libraries in implementing family literacy programmes, and the importance of this as an outreach programme, will be discussed.
\end{abstract}

\section{Introduction}

South Africa has a problem in that many of our children enter school without the requisite preliteracy skills, ie the reading and writing behaviours that precede and develop into conventional literacy, needed to become successful readers. The reasons for this are manifold, one of them being that many previously disadvantaged people do not come from a reading culture. Community libraries, through family literacy programmes, can go a long way towards equipping children with vital preliteracy skills. The Children's Literature Research Unit in the Department of Information Science, at Unisa in partnership with Project Literacy have undertaken a family literacy programme to address the problem of preliteracy skills. This project was started in 2000 in four creches and has now expanded to 16 sites in KwaZulu Natal, Eastern Cape, Free State, Limpopo Province and Gauteng. In addition we are developing a family literacy package including manuals for trainers and caregivers and a video demonstrating to parents/caregivers (even those who are illiterate) how to read to their children. This video will be available in five languages. In this article the project will be briefly described and initial results in one site discussed. The role that libraries can play in family literacy will also be briefly discussed. A library is the ideal site for family literacy training to take place as it enables the library to move into the community and address the needs of non-traditional users of a library.

\section{Socialisation of literacy}

Literacy is culturally bound and for this reason it is important for libraries to take account of literacy practices in the home and the broader social environment. Being literate involves more than acquiring the rudimentary skills of reading and writing. The sense of what literacy is derives from interactions with the family or significant others in the process of socialisation in addition to many concomitant factors in the social environment, such as the availability of public and community libraries. Family literacy practices in advantaged middle-class homes prepare children for the type of literacy they will encounter when they go to school. Parents read to preschool children and start to introduce them to the kind of questions they will be asked once they start school. Preliteracy skills are developed, such as learning how to hold a book properly, to turn the pages, and interpret the pictures. Having books read to them provides opportunities for children to learn how books convey meaning. They also learn basic uses of literacy through watching their family in literacy activities. For example, they see their mother making a shopping list, writing down a message or phone number, and consulting books to find something out. By the time these children go to school, even though they may not be able to read and write, they understand how books work and the role that literacy will play in their lives. This gives them an important advantage because school practices tend to focus on teaching decoding skills rather than teaching children how to take meaning from text or the ways in which literacy will be meaningful in their lives.

In contrast, children who come from a disadvantaged environment may never have encountered a book before coming to school and have no knowledge of how books work. These children are at a major disadvantage when they start school. It is difficult for them to imagine what use reading will be to them or how to make meaning out of what they read. Research shows that children who have not had important preliteracy experiences at home, such as being read to by a parent, will learn to read more slowly and be less successful at school, and this will affect them negatively not only in the 
initial stages, but throughout their school career (Heath 1983; Wells 1986). These children are unlikely to grow up to be readers. Although these studies took place in traditional nuclear families consisting of a mother, father and children, the results would be applicable to non-traditional families as well.

Literacy is not taught or learnt in a vacuum but takes place in a social context that either fosters or fails to support the development of literacy in the child. One of the factors that influences literacy in young children from disadvantaged environments is the lack of access to books which may critically influence parent participation and involvement in the educational experiences of their children (Lamme \& Russo 2002). Many disadvantaged communities have few resources available to them to enable them to provide their children with the opportunity to experience preschool storybook reading. Libraries can affect access to books by providing suitable books for young children. In addition they can provide training for the parents/ caregivers as to how to read storybooks to children.

\section{Family literacy}

One of the most successful strategies used in improving literacy in disadvantaged communities both overseas and in South Africa is family or intergenerational literacy. There is no universal acceptance of what the concept 'family literacy' means as programmes are diverse with different clientele, activities, materials and objectives. However, it can be accepted that the concept 'family literacy' encompasses a wide variety of programmes that promote the involvement of both parents or other family members and their children in literacy enhancing practices and activities. The main purpose of family literacy programmes is to improve the literacy of educationally disadvantaged children, based on the assumption that parents are the child's first and most influential teachers (Tett \& Crowther 1998: 450). The central element that these programmes have in common is consideration of the family as a learning unit. In South Africa many family units do not consist of the traditional two parents and children. A family unit in South Africa may consist of grandparent(s), aunt or uncle or even older siblings and younger children. This is becoming more common as a result of the impact of AIDS.

Parents or caregivers can be of valuable assistance in helping the child to become literate with a facilitator's guidance. Family literacy programmes in Britain, USA and South Africa have demonstrated the value of involving parents in the literacy process (Auerbach 1995; Come \& Fredericks 1995; Morrow \& Young 1997; Overett \& Donald 1998; Paratore 1995).

It is a good idea to start family literacy programmes with children who are as young as possible as research indicates that these programmes are more successful with younger children. For example, reading to children has been found to be more effective in younger children than in older children (Hardman \& Jones 1999: 222).

One of the strengths of family literacy is the potential for and inclusion of all family members. These programmes are not just for school-age or preschool children and their mothers - newborns and the elderly can also participate in literacy in the context of their family (Mayfield 1999: 92). This is a particular strength in South Africa where children are often part of a large extended family with whom they interact (Liddell \& McConville 1994: 4).

\section{Background to the family literact project}

The Family Literacy Project grew out of a discussion with Project Literacy (an NGO in the field of adult literacy). We found that we shared a common concern about adult neoliterates failure to retain literacy skills or remain in literacy programmes. Another shared concern was preschool children from disadvantaged families who often start school without the requisite preliteracy skills. We formulated a project, which could address both of these concerns, namely the family literacy project. A Foundation' situated in the USA expressed interest in funding the Children's Literature Research Unit in an initial pilot project in the year 2000.

\section{Aims of the family project}

The aim of the project is to train illiterate and neoliterate parents/caregivers how to read storybooks to preschool children in order to help children develop the preliteracy skills needed for school. Research shows that one of the most effective ways of preparing children for school and ensuring that they become successful readers is by reading stories to preschool children (Feitelson et al 1986). The idea behind the project was that in addition to benefiting the children it would also be beneficial to neoliterate adults. Many adults in adult literacy programmes drop out before they are fully literate for the following reasons:

- It takes a long time to master literacy skills and they become discouraged at their slow progress.

- There is often a lack of material at the correct level to enable them to practice their literacy skills.

- There are few meaningful literacy activities that they can participate in until their skills are more highly developed (Lindner 1998).

I. The Foundation requested that they remain anonymous. 
It was further hoped that by reading to preschool children adult new readers could gain confidence in their skills, get much needed practice before an uncritical audience and begin to play a more meaningful role in their child's education. Many parents/caregivers' with low literacy skills are reluctant to become involved in their children's education because they feel disempowered and unable to make a meaningful contribution. Reading to children could also help both the child and the adult realise how pleasurable reading can be. One of the reasons for the high levels of illiteracy and a-literacy in this country is that reading is seen as primarily linked to education and not something done for pleasure (Machet 2002:8).

\section{Methodology}

Initially it was planned that the project would be implemented with people already in adult literacy classes. These people would be trained how to read preschool children (either their own or children living in the house with them) and we would then be able to research two aspects: the effect of the intervention on the child's acquisition of preliteracy skills; and the effect on the adult learner's literacy. However, this was found to be impractical for the following reasons:

- Many of the adult learners did not have a child of a suitable age living with them.

- The adults often came from different areas and their children went to different creches or child care facilities. It would thus be difficult (if not impossible) to control the variables in the child's environment, which could affect the child's preliteracy skills. For example, one child might attend a creche with a well-qualified teacher who read regularly to the children while another might attend a child-care centre with no books and no stimulation. If we tried to compare these children at the end of the year in terms of preliteracy it would be difficult to know if the child from the creche with the well-trained teacher had made advances because of the intervention or because of the teacher.

It was thus decided that we would identify suitable creches and then invite the parents/ caregivers to attend a training session on how to read to the child. This training would be given in mother tongue by facilitators with whom we had workshopped the training process.

All the sites identified shared the following characteristics, which we felt were important:

- They had a strong principal or person in charge of the creche who was interested in being involved in the project.

- They were situated in an economically disadvantaged area.

- They had parents/caregivers who were interested in attending the training and prepared to participate in the project. In small communities it was also important to hold an initial meeting with the people to ensure that the community was willing for us to implement the project in the community.

After the site was identified and we had discussed the project with the person(s) in charge, we organised the first training session for the teachers, caregivers and parents. A day that suits all the parents/caregivers is arranged. If many of the parents/caregivers work then the training session will take place on a Saturday. The training session lasts approximately four hours. During that period the facilitator discusses the project with the parents, tells them about the importance of reading to their preschool children and demonstrates how to read to a preschool child. Parents/caregivers role play and practice reading to each other whilst the facilitator watches and helps parents/caregivers to improve their reading and interaction with the child. People attending the training session are also shown that one does not necessarily need to be literate to 'read' and share books with one's child. The text in a book is covered using masking tape and parents are divided into groups. They then each take a turn telling the story from the pictures. When the various stories are compared, parents can see that there are many similarities between the stories. Once they have seen how easily this can be done illiterate parents are prepared to 'read' other books to their children as well. Preschool children will not realise that the parent/caregiver is not actually reading the text and the parent/caregiver can teach the child many of the important preliteracy skills, such as holding the book correctly, turning pages, looking at the pictures. This can be very empowering for parents as they realise that in spite of having a low level of literacy they are able to contribute in a very meaningful way to their child's education.

A small library is set up in each creche or centre so that children and parents can borrow books on a regular basis. The running of this library is discussed in the training session and the parents formulate rules. The person in charge of the library will keep a record book where titles of books borrowed and person borrowing the book are recorded. As well as serving as a control and ensuring books are returned, it enables us to check which titles are most popular and whether there is a correlation between the number of books borrowed and the acquisition of preliteracy skills by the child. This is an important element of the research.

As far as possible we take cultural accessibility into account when selecting books to put in the library. Cultural accessibility and the language of the books have been identified as important elements in children's enjoyment and understanding of books (Saracho \& Dayton 199I; Shelley-Robinson 1996). The importance of cultural accessibility may be

I. In the interests of economy of expression the terms "parent" or "parent/caregiver" will be used. However, it can apply to any person with whom the child stays and who cares for the child ie grandparent, older sibling, aunt, uncle etc. 
illustrated by an anecdote from one of our sites in KwaZulu Natal. We had supplied a book with an illustration of a brown cow. The mothers objected to this saying that all the cows in the area were black and white and they did not want to read a book with their children that 'lied'. In spite of our assurances that brown cows do exist elsewhere we were eventually forced to remove the book. Cultural accessibility is a controversial issue. However our experience is that when children are first introduced to books they relate more easily to those that reflect an environment similar to their own.

Another aspect one needs to take into account is the lack of visual literacy. Many children's books have relatively sophisticated illustrations which children who have no experience of books or other visual media may have problems understanding. They usually prefer books with simple, realistic pictures.

Books are provided in the children's home language and we only place English or Afrikaans books in the library if specifically requested to do so and if the parents are literate in these languages. Research indicates that it is important that initial literacy experiences be in the child's mother tongue. We have had some problems obtaining suitable books as there are so few titles available in the indigenous languages but this situation is improving and we are finding a wider range of titles to choose from. We have supplied books in the following languages: Sepedi, Southern Sotho, Tswana, Xhosa, Zulu, Venda, English and Afrikaans. It was interesting to see in the Topsy Aids Village, one of the sites where we are working, that the children are taking out the books we have supplied in the indigenous languages in preference to beautiful books in English and Afrikaans that have been donated to the school.

The parents/caregivers are asked to formulate rules for the library as we feel it is essential that they take ownership of the library. We do give advice if the rules are not practical or too punitive (for example setting the fine for late returns at 50 cents per day). We also stress that no child is to be penalised for damaging or losing books. We do not want children to be excluded from the project because they have damaged books. Learning how to handle books and develop a respect for books is one of the lessons we hope children will learn. We have developed a poster illustrating how to care for books and this aspect is also discussed in the video. It is important to try and develop a positive attitude to books and reading and we feel if the rules are too strict this will not be possible. Also one has to take into account that these children are totally unfamiliar with books and the correct way to handle them.

At the end of the first session every child is given the book with which we had done the training. This is done for the following reasons:

- We want parents/caregivers to start reading with their child immediately and the best way to do this is to provide them with a book.

- We want parents/caregivers to feel confident when reading with the child. By giving them the book with which they had trained and are already familiar with, we ensure that the initial experience will be positive. Even if the parent/ caregiver is not a proficient reader s/he would know the story well enough to be able to be able to read it fluently.

- Parents/caregivers are given the option of taking a picture book without text if they prefer. Parents/caregivers have practised telling each other the story from this book based on the pictures as well as a book with text.

It is important that parents/caregivers are first trained as people who have not had the experience of being read to as a child are often unaware how to go about it. In addition research indicates that the way you read a story to a child is an important element in the effectiveness of the activity (Heath 1983; Stoll 1998: 24).

At the same time that the parents/caregivers are being trained, a fieldworker does the initial testing of the children.

Motivation is important as parents/caregivers and children often lose their enthusiasm after a while. We therefore carry out follow-up visits. They are initially carried out after two weeks and subsequently on a regular monthly basis. Follow-up workshops are run approximately three months after the first workshop to allow parents/caregivers to share problems with us or to get advice. We also feel these are important as it gives us an opportunity to teach parents/ caregivers more about reading with their children and to encourage them to keep up the reading with the children. New books are added to the library at workshops to keep children interested and to encourage and sustain participation. Another method used to sustain participation is offering a reward of books and a book bag for those children who have 'read' a certain number of books. We check this in the book in which the books borrowed are recorded. We also do an informal check on whether the child has actually had the stories read to them by asking a few questions about the books.

At the end of the year children are tested again. In addition, they are asked to name their favourite book and we then give this book to the child to keep. Asking the child to name their favourite book also indicates whether or not parents/ caregivers are reading to their children as those children who are not having books read to them are unable to name a favourite book.

In South Africa one of the problems with family literacy programmes in disadvantaged communities is that often the community in which one is working is not stable, for example in squatter camps. This can complicate the running of the programme because the community keeps changing. If one starts a programme in this sort of area it is a good idea to have an introductory meeting at fairly regular intervals where one acquaints new participants with the programme. It is 
important not to simply expect the new participants to join in with the other parents. They will not understand the rationale of the programme and parents who have already been on the programme for a while may become bored and impatient if training is repeated for the benefit of newcomers. However, it can be very beneficial to invite some parents who are well integrated into the programme to help with the training and motivating of new parents.

Children whose parents/caregivers were participating in the project were tested at the beginning of the programme. The testing was done in the children's home language. In order to provide a control group we evaluated children at the local school who had attended the creches the previous year so that we would have a baseline against which we would be able to measure the children the following year. We did this because we decided it would be unethical to have a control group by excluding certain children from participating in the project. However, it was essential to have a baseline against which we could measure the effect of the intervention. We needed children who, as far as possible, would have come from the same socio-economic circumstances and had similar preschool experience to the experimental group.

We initially implemented the project in the year 2000 in four sites in creches in Gauteng, two in Germiston, one in Winterveld and one in Mamelodi. We trained two facilitators how to train parents/ caregivers to read to young children. In the second year (200I) the project was extended to three sites in KwaZulu Natal. This enabled us to test the project in a rural environment. It also had the benefit that the population was more settled. One of the problems we had encountered was that the communities in the urban sites where we were working were very unstable which made longterm testing (even over the period of one year) problematic.

In July 2001 we were given a further grant by the Rockefeller Brothers' Fund to expand the project. We had developed a training manual for facilitators but this gave us the opportunity to refine the manual and also develop a manual for parents that they could take home after the initial training. In addition, we were now able to develop a video showing parents/caregivers how to read to preschool children. The video is in five languages: English, Afrikaans, Zulu, Xhosa and Sepedi. We also expanded the project to include a child-to-child model. This was done partly because of the impact of AIDS but also because we felt this would be beneficial to the children. In the child-to-child model we trained older children how to read to their preschool siblings or neighbours. We felt (based on research from overseas) that this would benefit both children. The older child would improve their reading skills and gain in self-esteem while the younger child would be able to acquire essential preliteracy skills.

The funds have enabled us to test the materials we have developed this year and make necessary changes. The manuals will be published next year and the video can be either remade (if necessary) or amended. We have also been able to have it translated into Zulu.

\section{Tests}

The aim of the tests was to assess whether the reading of storybooks to children in the preschool years help them develop preliteracy skills that form the basis for learning to read and write when they start school in Grade I. The children were tested in the following areas:

- Awareness of environmental print (e.g. knowledge of well-known logos such as Simba chips, Coca-Cola, Zambuck, etc.)

- Knowledge of letters of the alphabet

- Knowledge of numbers ( $1-10$ and 20)

- Story recall. This refers to the ability to retell a story that had been read to them by the facilitator. Children who can follow the events in a story and who understand what a story is about are better able to retell the story later. Children who fail to follow the story find it difficult to retell the story.

- Literacy behaviours. Here children are assessed in terms of their ability to hold a book the right way up, turn the pages in the right direction, know what things on the page tell the story (words or pictures), identify where the page number is, take an interest in the story, etc.

The children are all tested in their mother-tongue by a mother-tongue speaker. The storybook that is read to them is also in their mother-tongue.

\section{Report on findings of the family literacy project: Malunga Primary School (February 200 I - November 200I)}

The findings in one of the sites namely Malunga Primary School in KwaZulu Natal will be given here. Although there were some children's books in Malunga Primary School, they were all in English and not appropriate to the maturational level of the children. These books were stored out of reach of the children, and there was no spontaneous paging through books by the children. There was very little environmental print in the broader community and a dearth of environmental print inside the classrooms. The children were very well behaved and orderly, but there was little spontaneous or creative play, and activities were usually done in a group in a chanted choral style. Group activities typically involved singing songs 
in English or Zulu (especially songs where body parts or actions were acted out), naming the letters of the alphabet or counting in sequence in chorus. Judging from their behaviour the children had had very little experience with books; they were clumsy holding books and turned pages awkwardly. Some children were not even aware that they were looking at the books upside down, despite the fact that pictures were the wrong way up. The children's lack of familiarity with storybook reading was noticeable and sitting on the floor around the teacher's chair to listen to a story and follow the pictures in the book was clearly not part of their daily classroom routine.

During $200 \mathrm{I}$ an enriched preschool programme was established in the Grade R class at Malunga Primary School. This included, amongst other activities, a storybook reading programme that was established and funded by the Family Literacy Project. The Grade R teacher was encouraged to read storybooks on a regular basis to the children in her class. A collection of storybooks in Zulu was given to the class for this purpose. Mothers of some of the children in the Grade $R$ class were attending adult literacy classes and they too were required to read storybooks to their children on a regular basis. During the course of the year, some of the Grade R and Grade I children were tested to see what kinds of literacy skills they had developed.

\section{Grade 1}

Towards the end of February 200 I, 6 of the Grade I learners were tested on basic literacy skills. These were children who had been at school for about 7 weeks, and who had been in the preschool during 2000 but had not yet been involved in the Family Literacy Project. These children would provide the baseline or control group against which we could measure the children who were part of the project to see whether the intervention had made a difference.

\section{Grade R}

Four months later, in April 200I, several children in the Grade R class were tested on the same literacy test as used with the Grade I children. This is called the pre-test. The same children were then tested again in November 200I. This is called the post-test. The results of the pre- and post-test are then compared, to see whether the children have shown any improvement. The post-test was also compared with the baseline tests.

Results of the tests

The results of different parts of the tests for the different groups of children are shown in Table I below.

Table I Effects of storybook reading on preliteracy skills

\begin{tabular}{|c|c|c|c|c|c|c|c|}
\hline & $\begin{array}{l}\text { Mean } \\
\text { age }\end{array}$ & $\begin{array}{c}\text { environ } \\
\text { print } \\
\%\end{array}$ & $\begin{array}{l}\text { letters of } \\
\text { alphabet }\end{array}$ & numbers & $\begin{array}{c}\text { story } \\
\text { recall } \\
\%\end{array}$ & $\begin{array}{c}\text { handling } \\
\text { of books } \\
\%\end{array}$ & $\begin{array}{c}\text { book } \\
\text { behaviour } \\
\%\end{array}$ \\
\hline $\begin{array}{l}\text { Malanga Grade I } \\
(n=6) \\
\text { Feb 200I }\end{array}$ & 6,5 & 26,3 & 3 & 27 & 38,8 & 39,5 & 35,4 \\
\hline $\begin{array}{l}\text { Malanga Grade } \mathrm{R} \\
\text { Pretest }(\mathrm{n}=6) \\
(\text { April } 200 \mathrm{I}) \\
\end{array}$ & 5,6 & 34,7 & 13 & 42 & 50 & 27,7 & \\
\hline $\begin{array}{l}\text { Malanga Grade R } \\
\text { Posttest }(n=8) \\
(\text { Nov 200I) }\end{array}$ & & 55,2 & 29 & 69 & 65,9 & 48,4 & 37,5 \\
\hline
\end{tabular}

\section{Discussion of results}

The results show that the Grade $R$ children scored better on the literacy tests than the Grade I learners, even though they were on average one year younger than the Grade I learners. This showed up even in the pretest results in April, where the Grade R children on average scored better than the Grade I learners. By November 200I, the Grade R learners were more aware of environmental signs, they knew more letters of the alphabet and numbers, they understood storybooks better and in greater detail, and they were more familiar with literacy behaviours than their older Grade I peers. In other words, at the end of 200I, the Grade R children had better literacy skills than the Grade I learners had when they started school.

The results show that the children in the Grade $R$ class are benefiting from the family literacy programme and storybook reading. The Grade R children of 200 I who moved to Grade I in 2002 started school with a greater awareness of literacy practices and behaviours than their peers who started Grade I in 2000. Children who start school with this kind of awareness usually find it easier to learn to read and write. 


\section{Implication for the public or community library}

One of the major issues in the project is how to sustain and replicate it. We reach relatively few sites and although we have put small libraries in place we cannot continuously add to these libraries. As the children get older and start to require a greater diversity of books these cannot be supplied by the project due to limited funds. One of the ways in which these projects can be sustained and replicated is through public and school libraries. In KwaZulu Natal the person in charge of the project there has taken participants to the nearest public library. She first spoke to the public librarian and discussed the women's needs with the librarian. A special collection of easy-to-read and children's books in Zulu were provided for them. In addition it was arranged that the women could keep the books out for a longer period than is normally allowed because of the long distances that the women have to travel to come to the library. The cost of their travelling is also very high (R40.00 each). These women were initially very intimidated by the library and would not have joined the library without encouragement and support from their literacy teacher.

Libraries could play an important role in implementing family literacy projects in addition to offering support and resources. They could run the video, which shows parents how to read with their children, and then help to sign the parents and children up as members of the library. Our research has clearly shown us in a number of instances that it is not sufficient to simply make books available. Unless there is someone there who will show parents and children how to use the books effectively they will generally not be used. We visited a school that had been given wonderful books but these were kept in a locked room and were unused. Often school library rooms are used as storerooms that no one ever enters or uses except to store book donations. In the Topsy Aids Village, where we have one of our sites, we found a wonderful collection of donated books, which was largely unused. We are constantly made aware that people who do not come from a reading environment need encouragement and help to make use of books. This is not a change that takes place overnight but needs constant support and encouragement.

\section{Conclusion}

Family literacy programmes can be successfully implemented in public and school libraries and are in fact being implemented in these libraries in Britain and the USA (Lamme \& Russo 2002). Public and school libraries have the facilities and resources to sustain these programmes and to help children to become lifetime readers. Large sections of the population in South Africa do not come from a reading environment and are seriously disadvantaged in today's information society. Libraries need to be pro-active in encouraging these people to become library users and readers. The best place to start is with young children before they go to school. Libraries have traditionally run story hours for young preschoolers. However, in communities that are not library users parents and caregivers need to be shown and helped to use books with their young children. It is not enough to have libraries and to ensure that suitable books are purchased and available. We have to help the parents and caregivers who do not have high levels of literacy to use the books effectively to ensure that children become lifetime readers.

\section{References}

Auerbach, E.R. 1995. Which way for family literacy: intervention or empowerment? In Family literacy : connections in schools and communities, edited by Lesley Mandel Morrow. New Brunswick, New Jersey: Rutgers University: I I-27.

Come, B. \& Fredericks, A.D. 1995. Family literacy in urban schools: meeting the needs of at-risk children. Reading Teacher, 48(7):566-570.

Feitelson, D., Goldstein, Z., Iraqui, J. \& Share, D. 1986. Effects of listening to story reading on aspects of literacy acquisition in a diglossic situation. Reading Research Quarterly, 28:71-79.

Hardman, M. \& Jones, L. 1999. Sharing books with babies: evaluation of an early literacy intervention [I]. Educational Review, $5 I(3): 22 I-229$.

Heath, S.B. 1983. Ways with words: language, life and work in communities and classrooms. New York: Cambridge University Press.

Lamme, L.L. \& Russo, R. 2002. Project booktalk: library outreach to family daycare homes. Journal of Youth Services in Libraries, I5(3):36-40.

Liddell, C. \& McConville, C. 1994. Starting at the bottom: towards the development of an indigenous school-readiness program for South African children being reared at home. Early Child Development and Care, 97:1-15.

Lindner, R. 1998. Project Literacy. Personal interview, 7 September.

Machet, M.P. 2002. Literacy in disadvantaged South African communities and strategies to address this. Language Matters, 33:I24.

Mayfield, M. 1999. Family literacy programmes: intergenerational and international. International Journal of Early Education, $3 I(2): 9 \mid-98$.

Morrow, L.M. \& Young, J. 1997. A family literacy program connecting school and home: effects on attitude, motivation and literacy achievement. Journal of Educational Psychology, 89(4):736-742.

Overett, J. \& Donald, D. 1998. Paired reading: effects of a parent involvement programme in a disadvantaged community in South Africa. British Journal of Educational Psychology, 68: 347-356. 
Paratore, J.R. 1995. Implementing an intergenerational literacy project: lessons learned. In Family literacy : connections in schools and communities, edited by Lesley Mandel Morrow. New Brunswick, New Jersey: Rutgers University:37-53.

Saracho, O.N. \& Dayton, C.M. 1991. Age-related changes in reading attitudes of young children: a cross-cultural study. Journal of Research in Reading, I4(I):33-45.

Shelley-Robinson, C. 1996. The voluntary reading interests and habits of Jamaican sixth graders. Paper presented at Conference: International Association of School Librarianship, 25th Annual Conference, Jamaica, 30 July 1996. (Unpublished paper.)

Stoll, B.B. 1998. The effects of differential exposure to stories on second language discourse skills of pre-primary children. MA thesis, University of South Africa, Pretoria.

Tett, L \& Crowther, J. 1998. Families at a disadvantage: class, culture and literacies. British Educational Research Journal, 24(4):449-460.

Wells, G. 1986. The meaning makers: children learning language and using language to learn. London: Hodder \& Stoughton. 